\title{
Performance Characteristics of African Catfish (Clarias gariepinus) Fed Chicken Intestine
}

\author{
Olaniyi C.O ${ }^{1}$, Amusan A.O ${ }^{2}$ \\ ${ }^{1,2}$ Department of Animal Production and Health. ,Ladoke Akintola University of Technology, Ogbomoso .Oyo State, Nigeria
}

\begin{abstract}
The use of chicken intestine as a dietary protein source was experimented for its ability to replace fishmeal in the diet of Clarias gariepinus African cat fish. Five dried diets (40\% crude protein) formulated at $0 \%$ (control diet), $5 \%, 10 \%, 15 \%$ and $20 \%$ chicken intestine meal inclusion levels were fed to fingerlings of an average initial weight $16.02 \mathrm{~g}+/-0.2$. The experiment was conducted for 84 days and the growth parameters determined were as follows: mean weight gain (MWG), specific growth rate (SGR), feed conversion ratio (FCR). The five inclusion levels of chicken intestine meal supported the growth of Clarias gariepinus fingerlings however the growth and feed utilization were highly favoured by low inclusion of chicken intestine meal. Significant differences $(p<0.05)$ were observed among the treatments, $5 \%$ chicken intestine meal inclusion gave the best final mean weight gain of $47.27 \mathrm{~g}$ specific growth rate of $0.50 \%$, feed conversion ratio of 1.48 and protein efficiency ratio (PER) of 1.64\%. The carcass protein and lipid contents increased compared to the levels of both contents at the beginning of the experiment. Although, it was observed that the fish fed $10 \%$ chicken intestine gained more protein and lipid of $61.25 \%$ and $1.49 \%$ respectively, followed by $5 \%$ inclusion. However, the results showed that diet consisting of 5\% chicken intestine meal could be used as a replacement for fish meal in the diet of Clarias gariepinus fingerlings without any adverse effect.
\end{abstract}

Keywords: Replacement, protein source, diet, growth, chicken intestine

\section{Introduction}

In the recent past, around 1980s in Nigeria, it was discovered that the population growth outpaced that of fish food thereby increasing the demand for fish to meet the nutrient requirement of protein recommended by UNICEF for man. (NRC, 1993). $t$ Therefore the fisher men were trying to increase their yield and his actually led to overexploitation of capture fisheries. Hence the need for aquaculture to bridge the gap created between fish demand and supply in Nigeria to avoid malnutrition.

Today, aquaculture is the fast growing sector which supply one fourth of the fish consumed by man(World Reasource Institute, 2008). The total world aquaculture production in 2002 and 2003 were39.8 and42.3 million tones respectively (FAO, 2004). In 2003, Nigeria was ranked top 40 aquaculture producing nation ( FAO, 2005). Aquaculture has the potential to meet the high protein demand for both man and animals (NRC, 1993). In spite of this, Nigeria is still the highest importer of fish in Africa (FDF,2002). This great set back in the development and expansion of aquaculture in Nigeria and Africa at large has been associated with the cost of fish feed, particularly that of fishmeal, which is the major sources of protein in animal feeds However, limitation in the use of fish meal arose due to the unprecedented scarcity and increase in its price which has actually contributed to the drastic decline in fish production. . Therefore to meet fish protein requirement and production, there is need for exploring cheaper feed ingredients with little or no relevance in human nutrition. One of the most promising alternatives is the use of wastes as feed resources, such as feeding fish with rumen contents (Olaniyi,2010), cocoa husk (Falaye et al.,1999), as well as utilization of plantain peel in cat fish diet (Oloruntuyi, 1995; Falaye and Oloruntuyi, 1998). These actually showed that the use of locally available waste feed ingredients are now coming into existence.
Clarias gariepinus is a major species of aquaculture in Africa (Skelton 2001). It is cultured for its omnivorous feeding habit, high growth rate and its resistance to handling and stress ( Fagbenro and Davies , 2001; Turanand Akyurt, 2005).

This study therefore investigate the growth performance and nutrient utilization of African catfish (Clarias gariepinus) fed chicken intestine.

\section{Materials and Methods}

\section{Experimental Site}

The experiment was conducted at the fishery section of Teaching and Research farm of Ladoke Akintola University of Technology (LAUTECH), Ogbomoso.

\section{Experimental Fish}

A total number of 250 fingerlings were procured from a reputable hatchery in ogbomoso for this experiment. The fish were divided into five groups and fifteen fingerlings were allocated to a tank of 60litres capacity and replicated three times. The fish were acclimatized for two weeks. They were fed floating feed in order to empty their guts and prepare their appetite in readiness for the administration of the test diets.

\section{Processing of Chicken Intestine Meal (CIM)}

The chicken intestine used was obtained from a reputable poultry farm in Ibadan. The chicken intestine was oven dried, grinded and stored in a polythene sack to avoid spoilage.

\section{Experimental Diets}

Feed ingredients were procured from a reputable feed ingredient store in Ogbomoso. The major feed ingredients used were as follows: yellow maize, rice bran, fish meal, groundnut cake, blood meal. Others include Oyster shell, mineral premix, bone meal, lysine, vegetable oil and salt. 


\section{International Journal of Science and Research (IJSR) \\ ISSN (Online): 2319-7064 \\ Index Copernicus Value (2013): 6.14 | Impact Factor (2015): 6.391}

Five experimental diets were formulated: Diet 1 contained $0 \%$ of chicken intestine (control), Diet 2 (5\% CIM), Diet 3 (10\% CIM), Diet 4 (15\% CIM), and Diet 5 (20\% CIM) replacement level for fishmeal.

The feed were made into pellets with the use of pelletizing machine. Pellets were sundried for two days to reduce the moisture greatly and to prevent deterioration. The feeds were packed into sacks and stored ready for use.

\section{Feeding Regime}

The fingerlings were fed 3\% of their body weight daily. Feeding was done twice daily at 09:00hr and 16:00hr (morning and evening). The fishes were weighed every two weeks and their feeding regime was adjusted with respect to their body weight and survival rate. Water in the tanks were siphoned to get rid of the dirt.

Table 3: Gross composition of the experimental diet (g/100g)

\begin{tabular}{|c|c|c|c|c|c|}
\hline Ingredients & D1 & D2 & D3 & D4 & D5 \\
\hline Yellow maize & 24.45 & 23.45 & 23.05 & 22.45 & 21.95 \\
\hline Rice bran & 12.23 & 12.23 & 11.23 & 10.73 & 9.73 \\
\hline Fish meal & 36.45 & 34.63 & 32.8 & 30.98 & 29.16 \\
\hline Chicken Intestine & - & 1.82 & 3.65 & 5.47 & 7.29 \\
\hline Groundnut cake & 14.83 & 14.83 & 16.23 & 16.58 & 17.33 \\
\hline Blood meal & 7.29 & 8.29 & 8.29 & 9.04 & 9.79 \\
\hline Oyster shell & 1.5 & 1.5 & 1.5 & 1.5 & 1.5 \\
\hline Mineral premix & 1 & 1 & 1 & 1 & 1 \\
\hline Bone meal & 1.5 & 1.5 & 1.5 & 1.5 & 1.5 \\
\hline Lysine & 0.5 & 0.5 & 0.5 & 0.5 & 0.5 \\
\hline Salt & 0.25 & 0.25 & 0.25 & 0.25 & 0.25 \\
\hline Total & 100 & 100 & 100 & 100 & 100 \\
\hline Crude Protein & $40 \%$ & $39.99 \%$ & $39.75 \%$ & $39.68 \%$ & $39.70 \%$ \\
\hline
\end{tabular}
D - Diet

\section{Data Collection}

The parameters measured were Weight Gain; Average Daily Weight Gain;; Feed intake;

Each of these parameters was measured at 2 weeks interval. Performance characteristics were evaluated according to the method of Olvera- Novoaet al, (1990) as follows:

Mean Weight Gain (MWG) = Final mean weight (g) - Initial mean weight (g);

Average Daily Weight Gain $(\mathrm{ADWG})=$ Mean weight gain (g) / length of feeding trial (days);

Percentage Weight Gain (PWG) = Mean weight gain (g) /

Initial mean weight; $x 100$

Specific growth rate $\left(\right.$ SGR \% /day) $=100\left[\left(\log _{\mathrm{e}} \mathrm{W}_{2}-\right.\right.$

$\left.\log _{e} \mathrm{~W}_{1}\right) / \mathrm{N}_{\mathrm{O}}$ of days

Feed conversion ratio $($ FCR $)=$ total feed fed $(\mathrm{g}) /$ net weight gain (g);

Protein Intake $(\mathrm{PI})=$ total feed consumed X \% Crude protein in feed

Feed intake $(\mathrm{FI})=$ This is the amount of feed throughout the period of the experiment ;

Protein Gain (PG) = mean protein intake (g) / length of feeding trial (days);

Protein Efficiency Ratio (PER) = Net weight gain $(\mathrm{g})$ /

Amount of protein fed (g) while
Protein productive Value $(\mathrm{PPV})=$ protein gain in fish $(\mathrm{g}) /$

Protein in food (g ) x100.

Chemical Analysis

The test ingredient (chicken intestine), experimental diets and the fish samples were analysed for their chemical composition according to the procedure of A.O.A.C, (1990)

\section{Statistical Analysis}

All data collected were subjected to one way analysis of variance (ANOVA) using completely randomized design (CRD) in accordance with SAS (1999) and Duncan's multiple range tests was employed to reveal significant differences among the treatment means

\section{Results}

The proximate composition of chicken intestine meal (CIM) is as shown in Table 2 the crude protein (CP) content was $45.50 \%$ suggesting that CIM is a good source of protein for the fish particularly the Clarias gariepinus because CIM meets the protein requirement of Clarias gariepinus fingerlings.

The proximate compositions of the diets is revealed in Table 3. $40 \%$ crude protein were recorded for all the diets. The crude fibre ranged between $4.23 \%$ and $5.42 \%$ The ether extract and ash were also within the following range $4.16 \%$ $6.29 \%$ and $14.21 \%-8.29 \%$ respectively.

Table 4 revealed the growth performance of Clarias gariepinus fed varying inclusion levels of chicken intestine. Weight gain was observed in all fish at the end of the experiment. The FMW- final mean weight; MWG- mean weight gain; SGR- specific growth rate: FCR- feed conversion ratio, MFI- mean feed intake; PER- protein efficiency ratio; PI- protein intake; were all significantly different $(\mathrm{P}<0.05)$.

The mean feed intake of fish fed diet 1-5 are significantly different $(\mathrm{P}<0.05)$. Fish fed at $5 \%$ chicken intestine showed the highest percentage weight gain while the fish fed $15 \%$ chicken intestine showed the least percentage weight gain. In the same vein Treatment 2 had the highest specific growth rate of $0.50 \% /$ day followed by $\mathrm{T} 5(0.43 \% /$ day $)$. The lowest SGR $(0.26 \% /$ day) was recorded for the control (T1). Fish fed at $5 \%$ chicken intestine - T2 produced a better feed conversion ratio of (1.48 least value) compared to the other treatments. The highest protein efficiency ratio (PER) was recorded for T5 (2.16) followed by T2 (1.64). The least PER of 1.52 was recorded for T4 (15\% chicken intestine).

Table 5 revealed the carcass composition of the fish samples from the five treatments before and after the feeding trial. It was observed that fish fed $10 \%$ chicken intestine gained more protein and had the highest crude protein (61.25\%) while those fed with $20 \%$ chicken intestine had the least value (57.34\%). Fish fed with $10 \%$ chicken intestine gained more fat and has the highest crude fat $(1.49 \%)$ while those fed with initial diet has the least crude fat $(0.68 \%)$. Crude fibre value of all carcass are significantly different $(\mathrm{P}<0.05)$.

Fish fed with $10 \%$ chicken intestine has the highest value of ether extract (18.04\%) while those fed with initial diet has 


\section{International Journal of Science and Research (IJSR) \\ ISSN (Online): 2319-7064 \\ Index Copernicus Value (2013): 6.14 | Impact Factor (2015): 6.391}

the least ether extract (14.48\%). Initial diet has the highest value of ash (11.38\%) while diet with $15 \%$ chicken intestine has the least ash (7.37\%).

Table 2: Proximate Composition of Chicken Intestine Meal (CIM)

\begin{tabular}{|c|c|}
\hline Parameters & Percentage $\%$ \\
\hline Crude Protein & 45.50 \\
\hline Crude fibre & 2.15 \\
\hline Ether extract & 24.09 \\
\hline Ash & 3.42 \\
\hline Moisture & 7.56 \\
\hline
\end{tabular}

Table 3: Proximate Composition Of Experimental Diets

\begin{tabular}{|c|c|c|c|c|c|}
\hline & D1 & D2 & D3 & D4 & D5 \\
Parameters & Control (0\%) & $5 \%$ & $10 \%$ & $15 \%$ & $20 \%$ \\
\hline CP & 40.05 & 40.57 & 40.52 & 40.69 & 40.13 \\
\hline CF & 4.23 & 5.42 & 4.50 & 4.43 & 5.31 \\
\hline EE & 6.29 & 5.57 & 4.16 & 4.44 & 5.82 \\
\hline ASH & 8.29 & 11.68 & 14.08 & 14.21 & 13.29 \\
\hline MOISTURE & 15.71 & 11.81 & 10.48 & 14.13 & 10.12 \\
\hline
\end{tabular}

D1-Diet 1, D2-Diet 2, D3-Diet 3, Diet 4, D5-Diet 5. CPCrude protein,

CF- Crude fibre ,EE-Ether Extract
Table 4: Growth Performance of Clariasgariepinus Fingerlings Fed Chicken Intestine.

\begin{tabular}{|c|c|c|c|c|c|c|}
\hline & T1 & T2 & T3 & T4 & T5 & SEM \\
Parameters & $0 \%$ & $5 \%$ & $10 \%$ & $15 \%$ & $20 \%$ & \\
\hline IMW(g) & 16.09 & 16.01 & 16.04 & 16.02 & 16.24 & \\
\hline FMW(g) & $44.97^{\mathrm{c}}$ & $47.27^{\mathrm{a}}$ & $44.04^{\mathrm{d}}$ & $42.30^{\mathrm{e}}$ & $45.40^{\mathrm{b}}$ & 0.03 \\
\hline MWG(g) & $28.85^{\mathrm{c}}$ & $31.25^{\mathrm{a}}$ & $28.00^{\mathrm{d}}$ & $26.26^{\mathrm{e}}$ & $29.15^{\mathrm{b}}$ & 0.02 \\
\hline \%MWG & $179.46^{\mathrm{b}}$ & $193.16^{\mathrm{a}}$ & $174.33^{\mathrm{c}}$ & $163.92^{\mathrm{d}}$ & $179.40^{\mathrm{b}}$ & 0.03 \\
\hline SGR(\%) & $0.26^{\mathrm{b}}$ & $0.50^{\mathrm{a}}$ & $0.42^{\mathrm{a}}$ & $0.42^{\mathrm{a}}$ & $0.43^{\mathrm{a}}$ & 0.03 \\
\hline MFI (g) & $46.63^{\mathrm{b}}$ & $47.01^{\mathrm{a}}$ & $44.14^{\mathrm{d}}$ & $42.69^{\mathrm{e}}$ & $45.89^{\mathrm{c}}$ & 0.02 \\
\hline FCR & $1.61^{\mathrm{a}}$ & $1.48^{\mathrm{b}}$ & $1.54^{\mathrm{a}}$ & $1.61^{\mathrm{a}}$ & $1.55^{\mathrm{a}}$ & 0.03 \\
\hline PI & $18.65^{\mathrm{b}}$ & $18.78^{\mathrm{a}}$ & $17.64^{\mathrm{c}}$ & $17.09^{\mathrm{d}}$ & $13.34^{\mathrm{e}}$ & 0.03 \\
\hline PER & $1.55^{\mathrm{b}}$ & $1.64^{\mathrm{b}}$ & $1.57^{\mathrm{b}}$ & $1.52^{\mathrm{c}}$ & $2.16^{\mathrm{a}}$ & 0.03 \\
\hline
\end{tabular}

Mean a,b,c, d and e in the same row with different superscript are significantly different $(\mathrm{P}<0.05)$.SEMStandard Error of Mean; IMW-Initial Mean Weight; FCRFeed Conversion Ratio; MFI- Mean Feed Intake; PERProtein Efficiency Ratio; PI- Protein Intake; IMW- Initial Mean Weight; MFW- Mean Final Weight; MWG- Mean Weight gain; SGR- Specific Growth Rate

Table 5: Carcass composition of the fish before and after the feeding trial

\begin{tabular}{|c|c|c|c|c|c|c|c|}
\hline & & C I & C I & C I & C I & C I & S \\
Parameters & Initial & $0 \%$ & $5 \%$ & $10 \%$ & $15 \%$ & $20 \%$ & SEM \\
\hline C.P & $58.98^{\mathrm{a}}$ & $60.38^{\mathrm{a}}$ & $60.03^{\mathrm{a}}$ & $61.25^{\mathrm{a}}$ & $60.98^{\mathrm{a}}$ & $57.34^{\mathrm{a}}$ & 1.4 \\
\hline C.F & $0.68^{\mathrm{e}}$ & $1.11^{\mathrm{c}}$ & $1.27^{\mathrm{b}}$ & $1.49^{\mathrm{a}}$ & $0.97^{\mathrm{d}}$ & $1.06^{\mathrm{dc}}$ & 0.03 \\
\hline E.E & $14.48^{\mathrm{e}}$ & $15.75^{\mathrm{d}}$ & $16.39^{\mathrm{b}}$ & $18.04^{\mathrm{a}}$ & $16.12^{\mathrm{c}}$ & $16.22^{\mathrm{c}}$ & 0.04 \\
\hline ASH & $11.38^{\mathrm{b}}$ & $7.75^{\mathrm{d}}$ & $10.41^{\mathrm{b}}$ & $7.58^{\mathrm{ed}}$ & $7.37^{\mathrm{e}}$ & $8.45^{\mathrm{c}}$ & 0.05 \\
\hline MOISTURE & $9.59^{\mathrm{b}}$ & $8.51^{\mathrm{c}}$ & $7.74^{\mathrm{e}}$ & $10.51^{\mathrm{a}}$ & $8.19^{\mathrm{d}}$ & $9.68^{\mathrm{b}}$ & 0.05 \\
\hline
\end{tabular}

Mean a, b, c, d and e in the same row with different superscript are significantly different $(\mathrm{P}<0.05)$.C I- Chicken Intestine; C.P- Crude protein C.F- Crude fiber E.E- Ether extractSEM- Standard Error of Mean

\section{Discussion}

According to the result of the present study, gain in weight was observed in all fish at the end of the experiment. The growth of fishes were represented as a function of initial mean weight, mean food intake, feed conversion ratio and mean final weight. The lower the value of feed conversion ratio, the higher the feed conversion efficiency. Fish was being replaced by chicken intestine in feeding of Clariasgariepinus and at 5\% inclusion level, the highest percentage of weight gain was observed.

The highest value of mean feed intake was observed at 5\% substitution level with the minimum value obtained at $15 \%$ inclusion level of chicken intestine.

Abdel-Warithetal. (2001) reported 40\% replacement of fish meal with poultry by product meal without effectively altering growth in the diet of African catfish. This present study however, at 5\%- $20 \%$ inclusion, showed effective altering of growth of Clariasgariepinus. From the result obtained in this study, if $40 \%$ inclusion level was attained, there will be effective weight gain. The variation in this result from that of Abdel-Warith and Abdel- Wahab (2002) may be due to the percentage of other feed ingredients in the feed used as well as the environmental condition of the site.

In present study, SGR was not significantly higher in comparing T3, T4 and T5 which is contrary to results reported by Samocha et al. (2004) showing significant difference in SGR athigh inclusion.

In T2, T3 and T4, FCR increases as the level of inclusion of chicken intestine increases, this is in contrary to Goda et al., (2007) in African catfish (Clarias gariepinus) and Shapawi et al., (2007). They reported relatively low FCR by increasing percentage replacement of fish meal with chicken intestine.

Studies of Takagi et al. (2000), Davis and Arnold (2000) also support this result. According to them, by using good quality of high protein value poultry by-product, it could be possible to replace $75 \%$ or even $100 \%$ of fish meal without compromising on the fish growth. Sealey and Hardey (2011) reported that complete replacement of FM with PBM could be possible in the feed formulation by using good quality PBM without any addition of amino acids.

\section{Conclusion}

Diet 2(5\%CIM) had the best performance in term of MWG,FCR,PER, therefore, it can be concluded that chicken 


\section{International Journal of Science and Research (IJSR) \\ ISSN (Online): 2319-7064}

Index Copernicus Value (2013): 6.14 | Impact Factor (2015): 6.391

intestine meal can be included up to $5 \%$ in the diet of catfish.

\section{Recommendation}

Based on the result obtained from the experiment, it is hereby recommended that $5 \%$ chicken intestine meal can be included in the diet of Clarias gariepinus without any adverse effect

\section{References}

[1] Abdel-Warith and Abdel Wahab,A (2002): Sustainability of selected raw material and By-product in the formulated feeds for Nile Tilapia (Oreochromis niloticus) and African cat fish (Clarias gariepinus) . Plymouth Electronic Achive and Research Library (pearl)University of Plymouth, UK.

[2] A.O.A.C, (1990). Official Method of Analysis (K, Helrich, editor). Association of Official Analytical Chemists, Washington DC $15^{\text {th }}$ Edition, (1) 1094p.

[3] Davis, D. A. and Arnold C. R. (2000).Replacement of fish meal in practical diets for the Pacific white shrimp, Litopenaeusvannamei.Aquaculture. 185:291-298.

[4] Fagbemo. O.A. and Davies S.J..(2001). Use of soybeanflour (dehulled. solvent-extracted soybean) as fishmeal substitute in practical diets for African catfish, Clariasgariepinus(Burchelll822): Growth, feed utilization and digestibility. Journal of application of Ichthyol.. 17: 64-69.

[5] Falaye, A.E and Oloruntuyi , O.O (1998). Nutritive potential of plantain peel meal and replacement value for maize in the diets of African catfish. Clarias gariepinus fingerlings. Tropical Agric. Trinidad 75(4):448 - 492

[6] Falaye, A.E, Jauncey, K and Tewe, O.O(1999). The growth performance of Tilapia (Oreochromis Niloticus) fingerlings fed varying levels of Cocoa Husk diets. Journal of Aqua. Trop. 14(10): $1-10$.

[7] FAO(2004). Food Agriculture and Organisation year book of fishery statistics. 92/2.

[8] FAO (2005). The state of food and Agriculture. FAO Agriculture Series No. 36. ISSN 0081-4539

[9] FDF (2001). Fedral Department of Fisheries. Fisheries Statistics of Nigeria, 31p

[10] Goda.A.M .El-HarounE.R. and ChowdhuryM.A..(2007). Effect of totally or partially replacing fish meal by alternative protein sources on grovvth of African catfish, Clariasgariepinus(Burchell. 1822) reared in concrete tanks. Aquaculture Research• 38: 279-287.

[11]NRC (National Research Council) (1993) Nutrient requirements of fish.National Academy Press. Washington DC. $72 \mathrm{pp}$.

[12] Oloruntuyi, O.O (1995). Aquaculture and its implication for the Nigerian environment. Proceedings of the National Association of Aquatic Science, 210-219

[13] Olivera - Nova M.a, Campus,G., Sabido, G.M., and Martinez Palacois (1990).The use of alfalfa leaf protein concentrates as a protein source in the diets for Tilapia(Oreochromis mossambicus) Aqua. 90, 291 - 302
[14] Skelton, P. (1993). A Complete Guide to the Fresh water Fishes of Southern Africa. Halfway House: Southern Book Publishers Ltd.

[15] Sealey, W.M andHardy R.W. (2011). Evaluation of 100\% fish meal substitution with Chicken Concentrate, Protein PBM Blend, and Chicken and Egg Concentrate on Growth and Disease Resistance of Juvenile Rainbow Trout,Oncorhynchusmykiss. JournalWorld AquacultureSociety., 42(1): 46-54.

[16] Samocha, T.M.,. Davis D.A,.Saoud I.P andDeBault K. (2004).Substitution of fish meal by co-extruded soybean PBMmeal in practical diets for the Pacific white shrimp, Litopenaeusvannamei.Aquaculture., 231: 197-203.

[17] Shapawi, R., Wing-Keong Ng andMustafa, S. (2007). Replacement of fish meal with PBM meal in diets formulated for the humpback grouper, CromileptesaltivelisAquaculture., 273: 118-126.

[18] SAS (1999). Statistical Analysis Institute Inc. (SAS). Users guide. Version: $9^{\text {th }}$ Edition Statistical Analysis system Institute, Inc. Cary, NC, USA

[19] Turan, F. and AkyurtI., (2005). Effects of red clover extract on growth performance and body composition of African Clariasgariepinus. Fish. Sci., 71: 618-620. DOl: 10.1111/j.1444-2906.2005.01006.x.

[20] Takagi, S. T.,Hosokawa H., ShimenoS. andUkawa M. (2000). Utilization of PBM meal in a diet for red sea bream Pagrus major. Nippon Suisan Gakkaishi., 66: 428-438 